Journal of Animal and Veterinary Advances 11 (11): 1843-1846, 2012

ISSN: $1680-5593$

(C) Medwell Journals, 2012

\title{
Genetic Diversity of Silurus asotus on Mitochondrial DNA 16SrRNA Gene Partial Sequence
}

\author{
Wang Qing-Rong, Wei Zhi-Qin and Song Pei-Yong \\ Department of Biology, Zunyi Normal College, Zunyi, 563002 Guizhou, China
}

\begin{abstract}
The $600 \mathrm{bp}$ fragments of $16 \mathrm{SrRNA}$ gene were obtained by PCR Method from the mitochondrial DNA of Silurus asotus from four species groups and a mitochondrial DNA 16SrRNA of 540 bp sequence was successfully sequenced by Clustal X nomologous sequence analysis. The three upper branch groups are from Yalong Jiang in Sichuan province, Min river in Sichuan province and Wujiang river in Guizhou province, respectively. The middle branch group is from Wuyang river in Guizhou province. The genetic identity from $1 \sim 0.9980$ among groups and the genetic distance from $0 \sim 0.0020$ among groups were calculated by PopGen 32 . The results showed that there was no variation on the gene of the species groups from Wujiang river in Guizhou province. There were some variations on the gene of Yalong Jiang in Sichuan province, Min river in Sichuan province and Wuyang river in Guizhou province. The 4 individuality there were 4 haplotypes in Min river in Sichuan province. The 4 individuality there were 4 haplotypes in Yalong Jiang in Sichuan province. The 4 individuality only 1 haplotype in Wujiang river in Guizhou province. The 6 individuality there were 2 haplotypes in the middle branch group is from Wuyang river in Guizhou province. But there were some variations among the four species groups. The dendrogram of genetic relationship constructed by PopGen 32 indicates that they are divided into four branches.
\end{abstract}

Key words: Silurus asotus, mitochondrial DNA, 16SrRNA, genetic diversity, China

\section{INRODUCTION}

Silurus asotus belongs to Siluriformes, Siluridae, Silurus which located in the Changjiang river and in the larger rivers of the South Changjiang river (Xiang-Lin, 1977). From the early 1980 s, the artificial reproduction, nutrition, etc. have been gradually studied in China (Gang and Huaihui, 1994; Gang et al., 2005).

Mitochondrial DNA was widely used in fisheries studies due to its maternal inheritance, faster evolutionary rate than nuclear DNA and so on (Avise, 2000; Brown, 1983; Guo-Qing and Si-Fa, 1998; Khan et al., 2010). So far, the researches on fish mtDNA $16 \operatorname{SrRNA}$ gene sequence have been reported while limited studies on analysis of the genetic diversity of different populations of Silurus asotus according to the variants of $16 \mathrm{SrRNA}$ gene sequence (Zhou et al., 2004; Song et al., 2007).

Therefore, in this study, researchers measured the $16 S$ rRNA gene sequences of 18 individuals from four Silurus asotus species and analysed their genetic diversity which can contribute to the protection of fishes resources, genetic breeding and also, provide the basic information for the molecular genetic.

\section{MATERIALS AND METHODS}

Silurus asotus were collected from Yalong Jiang (Sichuan, China), Min river (Sichuan, China), Wujiang River (Guizhou, China), Wuyang river (Guizhou, China), respectively (Table 1). Tissue samples, i.e., skeletal muscle, liver, ovary were frozen in liquid nitrogen and then stored at $-20^{\circ} \mathrm{C}$.

Genomic DNA extraction: About $100 \mathrm{mg}$ liver or $200 \mathrm{mg}$ muscle was digested with the lysis buffer containing proteinase $\mathrm{K}\left(30 \mathrm{mmol} \mathrm{L}^{-1}\right.$ Tris- $\mathrm{HCl}, \mathrm{pH} 8.0,0.1 \mathrm{~mol} \mathrm{~L}^{-1}$ EDTA, $0.1 \mathrm{~mol} \mathrm{~L}^{-1} \mathrm{NaCl}, 1 \% \mathrm{SDS}$ ) at $55^{\circ} \mathrm{C}$ water bath for 2-4 $\mathrm{h}$ then extracted with phenol:chloroform:isoamyl alcohol (25:24:1) twice followed by chloroform: isoamyl alcohol (24:1) extraction and then with cold ethanol $\left(-20^{\circ} \mathrm{C}\right)$ precipitation DNA, dried and dissolved in $\mathrm{TE}$, the set stored at $-20^{\circ} \mathrm{C}$.

Table 1: Material origins, numbers and codes of Silurus asotus

\begin{tabular}{lcll}
\hline Original sources & Number & Codes & Numbers \\
\hline Yalong Jiang (Sichuan) & 4 & YLJ & YLJ1 YLJ2 YLJ3 YLJ4 \\
Min river (Sichuan) & 4 & MJ & MJ1 MJ2 MJ3 MJ4 \\
Wujiang river (Guizhou) & 4 & WJ & WJ1 WJ2 WJ3 WJ4 \\
Wuyang river (Guizhou) & 6 & WYH & WYH1 WYH2 WYH3 \\
& & & WYH4 WYH5 WYH6 \\
\hline
\end{tabular}

Corresponding Author: Wang Qing-Rong, Department of Biology, Zunyi Normal College, Zunyi, 563002 Guizhou, China 
Amplification and sequencing of $16 \mathrm{Sr} R N A$ gene: Primers P1:5'-GATTAGATACCCTGGTAGTCCAC-3' and P2: 5'CCCGGGAACGTATTC ACCG-3') which synthesized by Shanghai Biotechnology company were used for PCR amplification of the 16SrRNA gene. The total reaction volume is $50 \mu \mathrm{L}$ including template DNA $1 \mu \mathrm{L}$, each forward and reverse primer, $1 \mu \mathrm{L}\left(10 \mu \mathrm{mol} \mathrm{L}^{-1}\right), 10 \times$ Buffer $5 \mu \mathrm{L}, 25 \mathrm{mmol} \mathrm{L}{ }^{-1} \mathrm{MgCl}_{2} 5 \mu \mathrm{L}, 1$ unit of Taq DNA polymerase, make up the sterile double-distilled water to a final volume, add 2 drops of its disinfection paraffin oil. Thermocycling conditions of PCR reactions are as follows: denaturation at $92^{\circ} \mathrm{C}$ for $2 \mathrm{~min}$ followed by 35 cycles of denaturation at $92^{\circ} \mathrm{C}$ for $45 \mathrm{sec}$, annealing at $55^{\circ} \mathrm{C}$ for $45 \mathrm{sec}$, extension at $72^{\circ} \mathrm{C}$ for $1 \mathrm{~min}$ then final extension at $72^{\circ} \mathrm{C}$ for $10 \mathrm{~min}$. PCR amplification products were electrophoresed 2\% agarose gel (containing ethidium bromide $0.5 \mu \mathrm{g} \mathrm{mL}^{-1}$ ), observed by the UV lamp observation and took a photograph.

PCR products as templates for DNA sequencing were purified by using UNIQ-10 column PCR purification kit (Shanghai Sangon) and ABI 377 automated sequencer was used for two-way sequenced by using sequencing reagent Bigdye terminator 2.0 (Shanghai Sangon). All the sequencing were done in Shanghai biotechnology company.

Data analysis: The sequencing results were upload into the Clustal X and then manually check and choose $540 \mathrm{bp}$ homologous fragments for further analysis. PopGen32 Software was used to calculate genetic distance (Genetic Distance, GD) and genetic identity (Genetic Identity, GI) and the UPGMA (unweighted pair group method using arithmetic average) dendrogram of genetic relationship was also build.

\section{RESULTS AND DISCUSSION}

16SrRNA cloning: About $600 \mathrm{bp}$ fragments of $16 \mathrm{SrRNA}$ gene were amplified from different populations of Silurus asotus (Fig. 1).

Sequencing results of $16 \mathrm{Sr} R N A$ gene: Take the individual sequence of No. 1 Min river populations as the standard, the rest of the sequences were compared with the standard (Table 2).

Genetic distance and genetic identity: PopGen 32 Software was used to calculate genetic distance and genetic identity. Genetic distance varied from $0-0.0020$ and genetic identity varied from 1-0.9980 (Table 3 ).

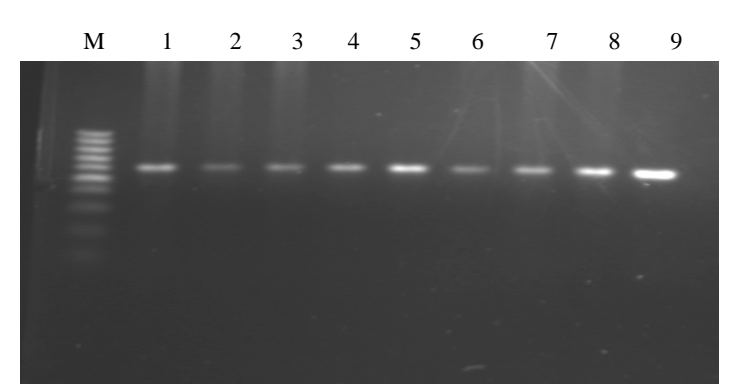

Fig. 1: The 16SrRNA gene PCR products of Silurus asotus. Marker: 100 bp ladder

Cluster analysis: According to the cluster analysis results by using PopGen32 Software, three populations of Yalong Jiang, Min river and Wujiang river clustered into one branch. Individuals 1 and 3 of Wujiang river are together from one branch while individual 2, 4, 5 and 6 are clusted into another branch then together again as one branch.

In this study, $16 \operatorname{SrRNA}$ gene fragments from 18 individual Silurus asotus of four populations were measured and the homology of the $540 \mathrm{bp}$ fragment were also analysis.

By comparison (Table 2), among the three populations of the upstream of the Changjiang river, researchers have analysised four individuals of the Min river which have four haplotypes and four individuals of Yalong Jiang which also have four haplotypes were analysised. Toward $16 \operatorname{SrRNA}$ gene, populations in Wujiang river basically have no variation due to the exactly same sequence of four individuals analyzed and the four individuals have only one haplotype. Six individuals in the Wuyang river of upstream the Yuanjiang river were analyed which contains two kinds of haplotypes. In various populations, 16SrRNA gene sequence of Silurus asotus has variation among intergroups and the variation among populations is more significant than the variation within populations. These results suggested that the genetic diversity of Silurus asotus is abundant in the populations from upstream and middle tributaries of the Changjiang river. This results are accordance with the previous publications of the 16SrRNA gene fragment by RFLP analysis (Wang et al., 2007) and cytochrome $\mathrm{b}$ gene (Wang and $\mathrm{Yu}, 2008$ ) sequence analysis.

Table 3, the genetic distance of GD range from $0-0.0020$ among the 18 individuals, the largest genetic distance is 0.0020 for the MJ4 and YLJ3 which taken from the Min river and Yalong Jiang, respectively while the lowest genetic distance is 0 for the populations of 
J. Anim. Vet. Adv., 11 (11): 1843-1846, 2012

Table 2: The 16S rRNA gene sequence of Silurus astus

\begin{tabular}{|c|c|c|c|c|c|c|}
\hline Codes & ------------------------ & - & |- & 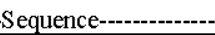 & - & 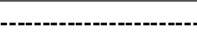 \\
\hline MJ1 & CCGTTGGGAG & CCTTGAGCTC & TTAGTGGCGC & AGCTAACGCA & TTAAGTTGAC & CGCCTGGGGA \\
\hline YLJ1 & - & - & - & - & - & $\mathrm{C}$ \\
\hline YLJ2 & - & - & - & - & - & $\mathrm{C}$ \\
\hline YLJ4 & - & - & - & - & - & $\mathrm{C}$ \\
\hline MJ1 & GTACGGCCGC & AAGGTTAAAA & CTCAAATGAA & TTGACGGGGG & CCCGCACAAG & CGGTGGAGCA \\
\hline MJ2 & - & - & - & - & $\mathrm{G}$ & - \\
\hline YLJ1 & $\mathrm{T}$ & - & - & - & - & - \\
\hline YLJ2 & $\mathrm{T}$ & - & - & - & G & - \\
\hline YLJ4 & $\mathrm{T}$ & - & - & - & G & - \\
\hline MJ1 & TGTGGTTTAA & TTCGAAGCAA & CGCGAAAAAC & CTTACCAGGG & CTTGACATCC & AATGAACTTT \\
\hline YLJ1 & - & - & $\mathrm{G}$ & $\mathrm{C}$ & - & - \\
\hline YLJ2 & - & - & G & $\mathrm{C}$ & - & - \\
\hline YLJ4 & - & - & $\mathrm{G}$ & $\mathrm{C}$ & - & - \\
\hline WJ & - & - & $\mathrm{G}$ & $\mathrm{C}$ & - & - \\
\hline WYH1 & - & - & G & $\mathrm{C}$ & - & - \\
\hline WYH4 & & & $\mathrm{G}$ & $\mathrm{C}$ & & \\
\hline MJ1 & CTAGAGATAG & ATTGGTGCCT & TCGGGAACAT & TGAGACAGGT & GCTGCATGGC & TGTCGTCAGC \\
\hline MJ1 & TCGTGTCGTG & AGATGTTGGG & TTAAGTCCCG & TAACGAGCGC & AACCCTTGTC & CTTAGTTACC \\
\hline MJ3 & - & - & - & - & $\mathrm{G}$ & - \\
\hline WYH1 & - & - & G & - & - & - \\
\hline MJ1 & TCGTGTCGTG & GGTGGGCACT & CTAAGGAGAC & TG-C-GTGACAA & ACCGGAGGAA & GGTGGGGATG \\
\hline YLJ1 & - & - & - & $\mathrm{C} \mathrm{G}$ & - & - \\
\hline YLJ3 & - & - & - & $\mathrm{C} \mathrm{G}$ & - & - \\
\hline YLJ4 & - & - & - & $\mathrm{C} \mathrm{G}$ & - & - \\
\hline WYH1 & - & - & - & $\mathrm{C} \mathrm{G}$ & - & - \\
\hline MJ1 & ACGTCAAGTC & ATCATGGCCC & TTACGGCCTG & GGCTACACAC & GTGCTACAAT & GGTCGGTACA \\
\hline MJ1 & GAGGGTTGCC & AAGCCGCGA & GTGGAGCTAA & TCCCACAAAA & CCGATCGTAG & TCCGGATCGC \\
\hline WJ1 & - & A & - & - & - & - \\
\hline MJ1 & AGTCTGCACT & TCGACTGCGT & GAAGTCGGAA & TCGCTAGTAA & TCGCGAATCA & GAATGTCGCG \\
\hline MJ4 & - & - & - & - & - & $\mathrm{T}$ \\
\hline YLJ1 & - & - & - & - & - & - \\
\hline YLJ1 & $\mathrm{AC}$ & - & - & - & - & - \\
\hline YLJ2 & $\mathrm{AC}$ & - & - & - & - & - \\
\hline YLJ4 & $\mathrm{AC}$ & - & - & - & - & $\mathrm{T}$ \\
\hline WJ1 & $\mathrm{AC}$ & - & - & - & - & - \\
\hline WYH1 & $\mathrm{AC}$ & - & - & - & - & - \\
\hline WYH4 & $\mathrm{AC}$ & - & - & - & - & $\mathrm{T}$ \\
\hline
\end{tabular}

-: The nucleotide absense

Wujiang river and Wuyang river. Genetic Identity (GI) range from 1-0.9980. The biggest is 1 for the two populations of the Wujiang river and Wuyang river and the minimum is 0.9980 for the MJ4 and YLJ3 which were picked up from the Min river and Wuyang river. It can be seen from Fig. 2 in the genetic relationship dendrogram, three populations of the Yalong Jiang, Min river and Wujiang river were clustered into a branch. Samples 1 and 3 from Wuyang river of Yuanjiang together for a small branch while samples 2, 4, 5 and 6 clustered into another branch, two small sticks together again for a general branch and then together with other samples.

Silurus asotus is the indigenous species usually live in some certain section of river and the individual normally is small, weak migration trends and geographic isolation. Each group is maintaining a relatively independent of breeding groups and the gene flow is relatively small for other inter-population. Therefore, the genetic composition of Silurus asotus is variated. Thus,

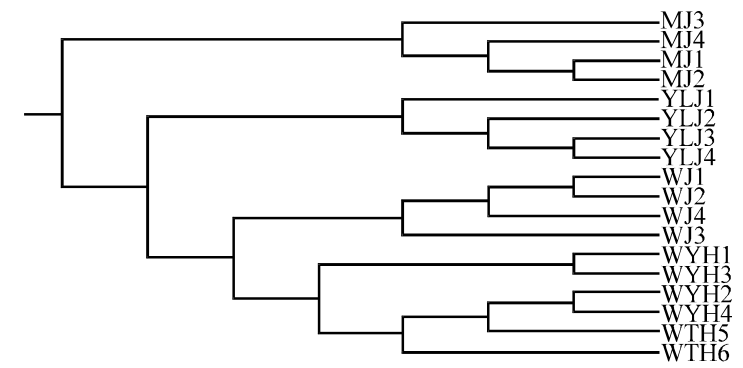

Fig. 2: Dendrogram of genetic relationship among the 18 isolates of Silurus astus

Silurus asotus 16SrRNA gene sequences have variations in the populations from upstream and middle tributaries of Changiiang river. Moreover, variation among populations is significant than the variation within populations and their genetic diversity is abundant. Genetic diversity which is an important component of biological diversity is an essential biological resources. Genetic diversity 
Table 3: Nei's genetic identity (above diagonal) and genetic distance (below diagonal) for isolates of Silurus astus \begin{tabular}{lllllllllllllll}
\hline pop ID MJ1 & MJ2 & MJ3 & MJ4 & YLJ1 & YLJ2 & YLJ3 & YLJ4 & WJ1 & WJ2 & WJ3 & WJ4 & WYH1 WYH2 WYH3 WYH4 WYH5 WYH6
\end{tabular} $\begin{array}{lllllllllllllllllllll}\text { MJ1 } & * * * * * * & 0.9998 & 0.9998 & 0.9998 & 0.9987 & 0.9987 & 0.9984 & 0.9984 & 0.9989 & 0.9989 & 0.9989 & 0.9989 & 0.9989 & 0.9991 & 0.9989 & 0.9991 & 0.9991 & 0.9991\end{array}$ $\begin{array}{llllllllllllllllllll}\text { MJ2 } & 0.0002 & * * * * * * & 0.9996 & 0.9996 & 0.9984 & 0.9984 & 0.9982 & 0.9982 & 0.9987 & 0.9987 & 0.9987 & 0.9987 & 0.9987 & 0.9989 & 0.9987 & 0.9989 & 0.9989 & 0.9989\end{array}$ $\begin{array}{llllllllllllllllllll}\text { MJ3 } & 0.0002 & 0.0004 * * * * * & 0.9996 & 0.9984 & 0.9984 & 0.9982 & 0.9982 & 0.9987 & 0.9987 & 0.9987 & 0.9987 & 0.9987 & 0.9989 & 0.9987 & 0.9989 & 0.9989 & 0.9989\end{array}$ $\begin{array}{llllllllllllllllllll}\text { MJ4 } & 0.0002 & 0.0004 & 0.0004 & * \text { ****** } & 0.9982 & 0.9982 & 0.9980 & 0.9984 & 0.9984 & 0.9984 & 0.9984 & 0.9984 & 0.9984 & 0.9987 & 0.9984 & 0.9987 & 0.9987 & 0.9987\end{array}$ $\begin{array}{lllllllllllllllllllll}\text { YLJ1 } & 0.0013 & 0.0016 & 0.0016 & 0.0018 \text { ***** } & 0.9996 & 0.9998 & 0.9996 & 0.9993 & 0.9993 & 0.9993 & 0.9993 & 0.9989 & 0.9996 & 0.9989 & 0.9996 & 0.9996 & 0.9996\end{array}$ $\begin{array}{lllllllllllllllllllll}\text { YLJ2 } & 0.0013 & 0.0016 & 0.0016 & 0.0018 & 0.0004 & * \text { ****** } & 0.9998 & 0.9996 & 0.9993 & 0.9993 & 0.9993 & 0.9993 & 0.9993 & 0.9996 & 0.9993 & 0.9996 & 0.9996 & 0.9996\end{array}$ $\begin{array}{lllllllllllllllllllll}\text { YLJ3 } & 0.0016 & 0.0018 & 0.0018 & 0.0020 & 0.0002 & 0.0002 & * * * * * * & 0.9998 & 0.9991 & 0.9991 & 0.9991 & 0.9991 & 0.9987 & 0.9993 & 0.9987 & 0.9993 & 0.9993 & 0.9993\end{array}$ $\begin{array}{llllllllllllllllllll}\text { YЛ/4 } & 0.0016 & 0.0018 & 0.0018 & 0.0016 & 0.0004 & 0.0004 & 0.0002 & * * * * * * & 0.9989 & 0.9989 & 0.9989 & 0.9989 & 0.9984 & 0.9991 & 0.9984 & 0.9991 & 0.9991 & 0.9991\end{array}$

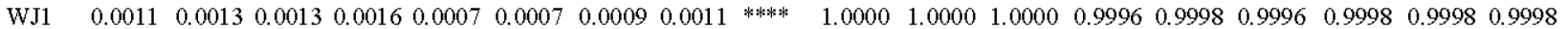
$\begin{array}{llllllllllllllllllll}\text { WJ2 } & 0.0011 & 0.0013 & 0.0013 & 0.0016 & 0.0007 & 0.0007 & 0.0009 & 0.0011 & 0.0000 & * * * * * * & 1.0000 & 1.0000 & 0.9996 & 0.9998 & 0.9996 & 0.9998 & 0.9998 & 0.9998\end{array}$

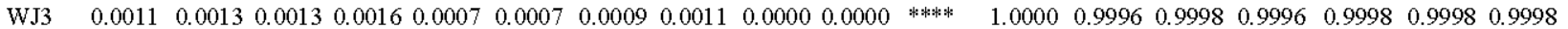
$\begin{array}{lllllllllllllllllllll}\text { WJ4 } & 0.0011 & 0.0013 & 0.0013 & 0.0016 & 0.0007 & 0.0007 & 0.0009 & 0.0011 & 0.0000 & 0.0000 & 0.0000 & * * * * * * & 0.9996 & 0.9998 & 0.9996 & 0.9998 & 0.9998 & 0.9998\end{array}$

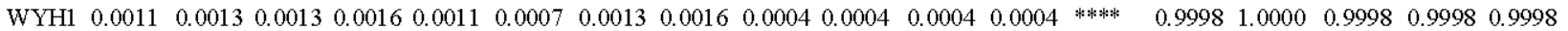

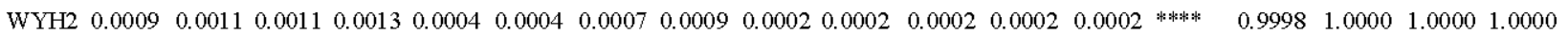
$\begin{array}{lllllllllllllllllllll}\text { WYH3 } & 0.0011 & 0.0013 & 0.0013 & 0.0016 & 0.0011 & 0.0007 & 0.0013 & 0.0016 & 0.0004 & 0.0004 & 0.0004 & 0.0004 & 0.0000 & 0.0002 & * * * * * * * & 0.9998 & 0.9998 & 0.9998\end{array}$ $\begin{array}{llllllllllllllllllllll}\text { WYH4 } & 0.0009 & 0.0011 & 0.0011 & 0.0013 & 0.0004 & 0.0004 & 0.0007 & 0.0009 & 0.0002 & 0.0002 & 0.0002 & 0.0002 & 0.0002 & 0.0000 & 0.0002 & * * * * * * * * & 1.0000 & 1.0000\end{array}$

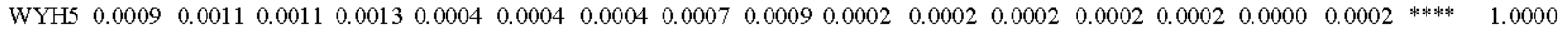

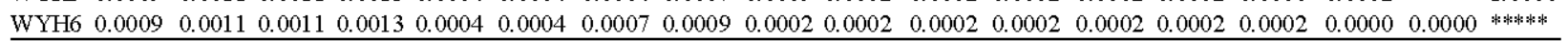

lossing cause to the permanent loss of human survival resources. With the development and rise of industrialization in the nearly two centuries, the natural environment has been artificially damaged continuously causing to deteriorating of ecological environment and significantly accelerated species extinction. Therefore, studies on the genetic diversity, conservation and sustainable use have become a urgent problem (Yan et al., 2004).

\section{CONCLUSION}

This study shows that there are high genetic diversity among different wild Silurus asotus populations which can contribute to strengthen protection of the Silurus asotus wild germplasm resources and prevent to overfishing and the adverse effects of invasive species. Therefore, this study have theoretical meaning for wild resources protection and management of Silurus asotus.

\section{REFERENCES}

Avise, J.C., 2000. Phylogeography. Harvard University Press, Cambridge, MA., London, Pages: 447.

Brown, W.M., 1983. Evolution of Animal Mitochondrial DNAs. In: Evolution of Genes and Proteins, Nei, M. and R.K. Koehn (Eds.). Sinaur Associates Inc., Sunderland, Massachusetts, pp: 62-128.

Gang, W. and C. Huaihui, 1994. A prelimianry histological study on the ovary development in the catfish Silurus asotus. J. Southwest China Normal Univ. Nat. Sci., 19: 517-521.
Gang, W., H. Lin and D. Dalin, 2005. A comparative study of the micro-structure and ultra-structure during the formation of envelope in oogenesis of fish (Silurus asotus). J. Southwest Agric. Univ., 27: 96-101.

Guo-Qing, L. and L. Si-Fa, 1998. Advances in the study and application of fish mitochondrial DNA polymorphism. J. Fishery Sci. China, 5: 94-103.

Khan, S.A., P.S. Lyla, B.A. John, C.P. Kuamr, S. Murugan and K.C.A. Jalal, 2010. DNA barcoding of Stolephorus indicus, Stolephorus commersonnii and Terapon jarbua of parangipettai coastal waters. Biotechnology, 9: 373-377.

Song, L., Z. Han and T. Gao, 2007. Sequence comparitson of two dorosomatinae species based on partial 16rRNA gene sequence. Trans. Oceanol. Limnol., 1: $125-129$.

Wang, Q. and X. Yu, 2008. Sequence conservation of cytochrome b gene of Silurus merdionalis. J. Southwest Univ. Nat. Sci. Edn., 30: 138-142.

Wang, Q., D. Wang and Q. Wang, 2007. RFLP of the amplified fragments of Mt DNA 16SrRNA gene of Silurus Asotus. J. Southwest China Normal Univ. Nat. Sci., 32: 104-107.

Xiang-Lin, C., 1977. A review of the Chinese siluridae. Acta Hydrobiol. Sin., 6: 197-216.

Yan, H., L. Gao, C. Fu and P. Mu, 2004. Molecular methods and advances on genetic diversity evaluation in fish. Fish. Sci., 23: 44-48.

Zhou, F.L., S.G. Jiang, T.F. Su and J.L. Lu, 2004. Comparative study of mtDNA 16S rRNA gene fragments among six lutjanus fishes. J. Fish. Sci. China, 2: 99-103. 